\title{
Sühreverdî̀nin İşrâk Düşüncesini İnşâda Kadim Etimolojilerin Yeri
}

\author{
Mehmet ALICI*
}

The Position of Ancient Etymologies

in the Construction of Suhrawardi's Ishraq Thought

Citation/C: Alıcı, Mehmet, (2014). The Position of Ancient Etymologies in the Construction of Suhrawardi's Ishraq Thought, Milel ve Nihal, 11 (2), 6181.

Abstract: In this article, it has been dealt with concepts that Suhrawardi, who is known as the founder of Philosophy of Ishraq, has used for explaining his system of thought. In this way, it has put forth that Suhrawardi has benefited for construction of his philosophy from the ancient concepts, which rooted in pre-Islamic Iranian thought basin. Meanwhile, this situation has indicated that the pre-Islamic Iranian thought has existed in conceptual level in the XIIth century. Besides, it brings to light that the masses, which Suhrawardi addresses, were aware of these etymologies.

Key Words: Suhrawardi, Zoroastrianism, Ancient Iran, Philosophy of Ishraq.

Atıf/C: Alıcı, Mehmet, (2014). Sühreverdî'nin İşrâk Düşüncesini İnşâda Kadim Etimolojilerin Yeri, Milel ve Nihal, 11 (2), 61-81.

Öz: Bu çalışmada İşrâk felsefesinin kurucusu olarak bilinen Sühreverdi'nin kendi düşünce sistemini inşa ederken kullandığı kavramlar ele alınmaktadır. Burada Sühreverdî’nin felsefesini inşa ederken İslam öncesi İran'ın düşünce havzasında yer etmiş kadîm etimolojilerden yararlandığı ortaya

* Yard. Doç. Dr., Mardin Artuklu Üniversitesi, İlahiyat Bilimleri Fakültesi [mehmetalici@artuklu.edu.tr] 
konulmaktadır. Bu durum, İran'ın İslam öncesi dini düşüncesinin varlığını XII. yüzyılda kavramlar düzeyinde devam ettirdiğini ve Sühreverdî’nin hitap ettiği kitlenin de bu etimolojilerden haberdar olduğunu açığa çıkarmaktadır.

Anahtar Kelimeler: Sühreverdî, Mecûsîlik, Kadîm İran, İşrâk Felsefesi.

\section{Giriş}

XII. yüzyılın ikinci yarısında İslam coğrafyasını dolaşarak dönemin âlimlerinden dersler alan Sühreverdî (ö. 587/1191), İslam felsefesi içerisinde İşrâkî düşünceyi esas alan yeni bir okulun inşasına girişmiştir. İşrâk felsefesinin kurucusu Sühreverdî kendi düşünce sistemini oluştururken birçok yeni kavram ihdas etmiş yahut mevcut kavramları yeniden resmetmiştir. Konumuz bağlamında Sühreverdî'nin kadîm İran dinlerinden özellikle Mecûsî geleneğine dair kavramları kullandığı görülmektedir. Farsça ve Arapça yazdığı metinlerde bu terimlere yer vermesi hitap ettiği kitlenin zihinsel altyapısına uygun bir tarz geliştirme çabası olarak yorumlanabilir ki bazı risalelerin adında kadîm bir etimolojiyi görmek mümkündür. Mesela, 1şık, şua ve nur anlamlarına gelen "Pertev" sözcüğünü Perteonâme adlı metnine başlık olarak koymuştur. Yine, Mecûsî geleneğinde tapınılmaya layık olan tanrı anlamına gelen ve aslında çoğul bir kavram olan "Yezdân" kelimesini Yezdân-Şinaht risalesini adlandırmakta kullanmaktadır. Bu durum Sühreverdî'nin Mecûsî geleneğine oldukça aşina olduğunu gösteren kimi unsurlar arasında sayılabilir. Bu çalışmada Sühreverdî'nin işrâk felsefesini inşa ederken özellikle Hikmetu'l-Işrâk' ta yararlandığı bazı etimolojiler ve bunların kadîm İran dinî geleneğindeki karşılıkları ve anlam örgüleri üzerinde durulacaktır.

\section{Ateş}

Sühreverdî'nin, yetiştiği medeniyet havzasının artalanını kullandığ ve felsefesini inşa ederken kadîm etimolojiden yararlandığı görülmektedir. Mesela onun, ateşe yaklaşımı bu etkileşime misal verilebilir. Sühreverdî, anâsır-ı erbaa' dan sayılan ateşin, aslında bağıısız bir unsur olduğu fikrini savunmaktadır. Ona göre ateş hemen havaya dönüşen ve onun berzahı olan havanın kendisinden yitip giden bir şeydir. Ateşin çabucak latifleştiğini ve havada ondan bir eser 
kalmadığını belirterek onun; su, toprak ve hava gibi bir unsur olmadığını ileri sürmektedir. ${ }^{1}$ Bu noktada Sühreverdî, kadîm geleneğe yönelir ve Farslıların ateş hususundaki düşüncelerini adeta paylaşır tarzda zikreder. Ateşin, nuru sebebiyle kıymetli olduğunu kadîm dönemde de onun Ordubihişt'in (Aşa Vahişta) tılsımı olarak kabul edildiğini ifade eder. Zira Ordubihişt Mecûsî geleneğinde ilk yaratılan altı ilahi varlıktan biri olup ateşle ilişkilendirilmektedir. Ordubihişt'in ateşin heykel efendisi olduğunu ve ondan taştığını dile getirmesi ${ }^{2}$ aslında onun ne denli Mecûsî terminolojisine hâkim olduğunu göstermesinin yanında bu etimolojinin alt yapısını ne kadar kabullendiğini de göstermektedir.

Sühreverdî kendi düşüncesi içerisinde ateşe yer verirken hareket ve sıcaklık kavramlarını da ele almaktadır. Nur olmadan hiçbir şeyin olmayacağını, hareketin ve sıcaklığın nurdan kaynaklanmasından dolayı, öfke ve şehvette sıcaklığın bir etkisinin olduğunu kabul eder. Dolayısıyla varlığa canlılık veren şeyleri hareket ve sıcaklık olarak tasvir etmesi, aslında ateşin durumunu daha anlaşılır kılma çabasının tezahürü olarak görülebilir. En yüce harekete ve en üst sıcaklığa yakın şeyin ateş olmasının, onun kıymetini ortaya koyduğunu düşünür. Sühreverdî'ye göre ateş, hareketin en yücesine, sıcaklığın en tamına sahiptir. Hayatın tabiatına en yakın olandır. Karanlıklarda ondan yardım istenir (istianede bulunulur). Nurlu olmasından dolayı ilkelere en benzer olandır. İnsani nefsin (ennefs'ul-isfehbed'in) kardeşidir. Sühreverdî'nin bu noktada kadîm İran'da Farslıların ateşe teveccühü emrettiklerini ve gerekçesinin de mezkûr durum olduğunu zikretmesi hayli ilginçtir. Zira ona göre Nûru'l-Envâr olan Allah da bütün nurlara tazimi gerekli görmüştür. ${ }^{3}$ Benzer şekilde Mecûsî geleneğinde ateşe, onun heykel efendisi ve Ameşa Spenta olarak bilinen altı yüce varlıktan biri olan Ordubihişt'e tazim söz konusudur.

\footnotetext{
Şihabüddin Sühreverdî, Hikmetu'l-İşrâk, Mecmua-i Musannefat-ı Şeyhi'l-İşrâk, thk. Henry Corbin, Seyyid Hüseyin Nasr, Necefkuli Habibi, Pejûheşgah-1 Ulum-u İnsani ve Motaleat-1 Ferhengi, Tahran 2001/1380, II, s. 188-191.

Sühreverdî, Hikmetu'l-İşâk, s. 156-157, 193.

3 Sühreverdî, Hikmetu'l-İşâk, s. 196-197.
} 
Mecûsî teolojisine bakıldığında Gatha' da Zerdüşt, tanrı Ahura Mazda ile ilgili olarak "senin alevli ateşin" 4 ifadesine yer vermektedir. Sonraki Avesta metinlerinde kendisine yakarılan bir varlık haline gelen ateş, Sâsânî teolojisinde kozmosta var edilen ilk yedi varlıktan biri olarak karşımıza çıkmaktadır. ${ }^{5}$ Zerdüşt ateşi, Ameşalardan Aşa Vahişta ile ilişkilendirmiş olsa da, ateşin mabedin merkez figürü ve liturjinin olmazsa olmazı haline gelmesi ondan sonraki dönemlerdedir. Fakat erken dönemlerden itibaren ateş Ahura Mazda' ya yakarma esnasında varlığından inayetle söz edilen ve Ahura Mazda'ya yaklaştıran bir unsur olarak görülmüştür. Özellikle Sâsânîler döneminde kurumsal bir unsur olarak mabedin merkezi ve ilâhî âlemle bağlantının aracı unsuru haline gelen ateş, Avesta edebiyatında Ahura Mazda'nın oğlu olarak takdim edilmekte ve tapınılmaya layık varlıklar kategorisine dâhil edilmektedir. ${ }^{6}$

Ahura Mazda'nın manevî ateşi ile maddî ateşin ilişkisi, dini ayinlerde insan ile tanrısal âlem arasındaki bağın sağlayıcısı, bir anlamda ilâhî ilhamın işitilmesini ve dileklerin tanrıya ulaştırılmasını sağlayan temel unsur olmasıyla sağlanmaktadır. İşte bu noktada maddî ateş, adeta Ahura Mazda'nın görünür yanı olarak tezahür etmektedir. Bu bağlamda ritüelin gerçekleştirilmesinde ateşin uygun şartlar altında hazır hale getirilmesi, Ahura Mazda'nın ilhamının doğru şekilde alınmasını sağlamaktadır. Aynı şekilde ateşin uygun koşullarda yakılmasından sonra kötü varlıklara karşı koruyucu bir unsur haline geldiğine inanılmaktadır. Ateşin tapınılan bir varlık olarak tasvir edilmesi, aynı zamanda onun mabedde sürekli yanıyor

4 Yesna. 31.19; Mecûsîliğin kutsal metin literatürü Avesta' nın bölümleri için İbrahim Purdavud'un Avesta tercümelerine Gatha; Kuhenterin bahşayi Avista, (Tahran, 1377), Horde Avesta, (Tahran, 1310), Vendidad, (Tahran, 1347), Visperad, (Tahran, 1343), Yesna I, (Tahran, 1340), Yeştha I-II, (Tahran, 1347), ve Prods O. Skjærvø'nun Zoroastrian Texts (2007) adlı çevirisine müracaat edilebilir.

5 Zand-Akasih-Iranian or Greater Bundahisn, trans., Behramgore T. Anklesaria, Bombay, 1956, I. 19-20, s. 7-9.

6 Ahura Mazda'nın oğlu olarak tasvir edilen ateşin beslenmesi Y.62.01-07; Ateşin etkinliğiyle Ahura Mazda'ya yakarılması Yesna 36.01; Krallar ve kahramanların kurdukları ateşler, Pahlavi Texts I Bundahisn, Trans. Edward W. West, Sacred Book of East, ed. Max Müller, Clarendon, Oxford University Press, 1880, XVII.57, s. 64-65; Kaikhusroo Jamaspasa, "Fire in Zoroastrianism", K. R. Cama Oriental Institute Third International Congress Proceedings, Mumbai, Jenaz Printers, 2000,s. 140-144. 
halde canlı tutulmasını gerektirmiştir. Bu tapınma eylemi, Mecûsî dinî edebiyatında ateşe yakarmayı öngören ve günlük beş temel duadan biri olan Ateş Niyayiş metninin oluşmasını sağlamıştır. ${ }^{7}$

Ateşin Ahura Mazda'nın en yakınındaki bir varlık olarak tasnif edilmesi, onun doğruluk ve hakikat olan Aşa Vahişta'yla (Ordubihişt) ilişkilendirilmesinin de alt yapısını oluşturmaktadır. Ateşin kötülüğü ve karanlığı giderici bir unsur oluşu, adalet ve düzenin ilkesi Aşa'nın sembolü olmasını açıklar mahiyettedir. Ahura Mazda'nın en yakınında olan dünya ve evrenin kozmik ilkesi olarak kabul edilen Aşa Vahişta, kötülüğün karşısında doğruyu, hakikati ve düzeni temsil etmektedir. Kozmolojik açıdan bakıldığında yokluk olan karanlığın karşısında var olanı, mevcudu sembolize etmektedir. ${ }^{8}$ Sühreverdî́nin ateş ve onun sahibi olarak Aşa Vahişta'yı/Ordubihişt'i öngörmesi, Mecûsî teolojisini iyi bildiğini ortaya koymaktadır. Bunun yanı sıra, onu tazime layık varlık olarak takdim etmesi oldukça dikkat çekicidir.

\section{Heykel Efendiler ya da Ameşa Spentalar}

Sühreverdî'nin Heykel Efendiler şeklinde dönüştürerek adeta yeniden kullanıma açtığı Ameşa Spentaların, kadîm gelenekte nasıl algilandığı sorusunun cevabı aynı zamanda Şeyh'ul-İşrâk'ın felsefesinde nasıl kavramsallaştırıldığına da açıklık getirmektedir. Mecûsî teolojisinde tanrı Ahura Mazda'nın en yakınında olan varlıklar olarak tasnif edilen ve tarihsel süreç içerisinde dönüşen teoloji içinde farklı anlam örgülerine sahip olan ve 'kutsal ölümsüzler' olarak çevrilebilecek Ameşa Spentaların Ahura Mazda'ya göre konumları tartışma konusu olmuştur. Kimi zaman Ahura Mazda ile zatsıfat ilişkisi içerisinde ele alınan bu üstün varlıklar, ${ }^{9}$ kimi zaman

7 Yesna. 1.12, 16.04, 17.01-11, 33, 36.01-06, 62.01-12; Ateş Niyayiş. 1-7, 01-18, 5.0118; Yeşt. 19.34-50; Almut Hintze, A Zoroastrian Liturgy, Wiesbaden 2007, s. 132135, 140; Firoze Kotwal; James Boyd, Persian Offering The Yasna: Zoroastrian High Liturgy, Paris, Studia Iranica, 1991, s. 13; Jamaspasa, “Fire in Zoroastrianism”, s. 141.

8 Aşa ve ateşe birlikte yakarılması Yesna. 1.04, 2.12; Sirozh 2.7; Erimiş metal gibi olan Aşa'yla Zerdüşt'ün Angra Mainyu'yu yakması, Yeşt. 17.20; Yalanın, hilenin ve zulmün karşıtı ve yok edicisi ve Zerdüşt'ün çağrısına yanıt veren Aşa, Yeşt. 3.03, 3.14-19; Ebedi hayata götüren Aşanın yolu Yesna. 72.11, 40.02; Aşa'nın dünyada hâkim olmasına çalışan Zerdüşt ve Kavi Viştasp Yeşt. 13.88, 13.99, 19.93.

9 Senin ateşin.. Yesna-Gatha. 34.04, 43.09, 46.07, 47.06; ... Sen kesinlikle Ahura Mazda'nın ateşisin, sen kesinlikle onun hayat veren esinisin... Yesna-Gatha 36.01; "Yüceler yücesi Ahura Mazda ve (siz) Armaiti ve Aşa ve hayatı zenginleştiren 
Ahura Mazda'dan ayrı tapınılmaya layık varlıklar olarak tezahür etmiştir. ${ }^{10}$ Bütün bu farklı algılamalara karşın Sâsânî teolojisi bu varlıkları, kozmoloji bağlamında yaratılan ilk varlıkların koruyucuları ve insanın iyi olan karakter ve mizaçlarının kaynağı olarak resmetmektedir. Bunun da ötesinde dünyada aslî unsurların sahipleri oldukları kadar insan uzuvlarının da Ameşalara atfedildiği bilinmektedir. Beden Behmen'e (Vohu Manah), damarlar ve yağ Ordubihişt'e (Aşa Vahişta), kemikler Şehrevar'e (Kşatra Vairya), ilik İsfendermend'e (Spenta Armaiti), kan Hordad'a (Haurvatat) ve saçlar Mordad'a (Ameretat) atfedilmektedir. Maddî unsurların Ameşalarla ilişkilendirilmesinin yanı sıra insan hayatını anlamlı ve anlaşılır kılan manevî ilkelerin de bu varlıkların hâkimiyeti altında görülmesi söz konusudur. Buna göre Behmen barışın, Ordubihişt doğruluğun, Şehrevar akrabaya yardımın, İsfendermend saygı ve hürmetin, Mordad danışma ve ölçülülüğün, Hordad lütuf ve cömertliğin kaynağı ve yasası olduğu kabul edilmektedir. ${ }^{11}$

Mecûsî kozmolojisini detaylarıyla bildiği anlaşılan Sühreverdî, yaratılışın başlangıcında yaratılan ve bütün varlıkların prototipi olan yedi varlığın koruyucuları olarak takdim edilen Ameşa Spentaları yerli yerinde kullanmaktadır. Onları, varlık âlemindeki her türün efendisi olarak kabul etmektedir. Yani, nur âlemindeki bu üstün

Vohu Manah, Kşatra bana kulak verin.. Yesna-Gatha 33.11; Spenta Mainyu ve Vohu Manah vasitasıyla, amel ve Aşa'ya uygun söz vasitasıyla, onlar, Ona Haurvartat ve Amertat'i verecekler. Hâkimiyete sahip olan Mazda, Armaiti sayesinde Ahura'dır. Yesna-Gatha 47.01.

10 Ahura Mazda'ya kurban sunarız, doğrulukla hükmeden Ameşa Spenta'lara kurban sunarız...Yesna 35.01; Biz Vohu Manah'a iyi Kşatriyaya, iyi Daenaya, iyi Fseratuya ve iyi Armaiti'ye kurban sunarız.. Yesna 37.04-05. Ameşa Spentaların yardıma çağrılması Vendidad. 19.11-15; Biz Ameşa Spenta'lara taparız... Biz, bol rızık veren aziz Ahura Mazda'ya taparız...Yeşt 1. 22-23.

11 Dünyada var edilen ilk yaratıkların Ahura Mazda ve Ameşalar tarafından alınmas1, korunması ve idame ettirilmesi Anklesaria, Greater Bundahishn III.11-17, s. 30-39; Pahlavi Texts I, Shayast la Shayast, Trans. Edward W. West, Sacred Book of East, ed. Max Müller, Clarendon, Oxford University Press, 1880, XV. 5-6, 25-30, s. 373, 378; İnsan bedenini oluşturan kısımların Ameşalara atfedilmesi Anklesaria, Greater Bundahishn, XXVIII.22, s. 252; İnsan hayatındaki manevi ilkelerin Ameşalarla ilişkilendirilmesi Aturpet-i Emetan, Dinkard VI: The Wisdom of Sasanian Sages, trans. Shaul Shaked, Colorado, Westview Press, 1979, (114), (E45h), s. 46-47, 214-215; İnsanın zihni ve manevi boyutunun Ameşalar tarafından korunmas1 Aturpet-i Emetan, Denkard VI, Ia-Ib-Ic, s. 2-3, 224-229. 
varlıklardan kahir nurların husûl etmesi, maddî âleme kadar uzanan bir süreçte devam etmektedir. İşte maddî âlemdeki varlık türlerinden her birinin kaynağı bu varlıklar olarak karşımıza çıkmaktadır. ${ }^{12}$

Sühreverdî, Mecûsî geleneğinde zikredilen ve tanrı Ahura Mazda'nın yanında resmedilen ilâhî varlıklara, Ameşa Spentalara kendi düşüncesini anlatırken yer vermeyi sürdürmektedir. Ona göre Hordad nurlar âleminin bir efendisi olarak suyun heykel efendisi/sahibidir. Bitkilerin/ağaçların efendisinin Mordad ve ateşin efendisinin de Ordibihişt olduğunu ifade etmektedir. ${ }^{13} \mathrm{Bu}$ bağlamda Mecûsî geleneğinde yaratılışın başında Ahura Mazda'nın yarattığı ilk varlıklardan suların koruyucusu olarak kabul edilen Hordad, bunun yanı sıra birçok hususta kendisinden yardım dilenilen ve yakarılan adeta tanrısal bir figürdür. Hordad'la birlikte Mecûsî teolojisinde zikredilen bitkilerin koruyucusu Mordad ise Zerdüşt'ün Gatha'sında ölümsüzlükle ilişkilendirilmekte ve canlılığın timsali ve ölüm ile yokluğun karşıtı olarak tanımlanmaktadır. ${ }^{14}$

Sühreverdî’nin bahse konu ettiği bir diğer Ameşa Spenta ise İsfendermez'dir. Mecûsî geleneğinde yüce tanrı Ahura Mazda'nın en yakınında olan Ameşa Spentalardan İsfendermez dişil olarak tasvir edilmektedir. Toprağın daha doğrusu cevheri toprak olan (bitki hayvan ve insan) her şeyin heykel efendisi/sahibi İsfendermez'dir. ${ }^{15}$ İşte tam da bu noktada Sühreverdî, onu kahir nurlardan biri olarak kabul etmekte ve manevî dünyadaki varlıkların kaynağı olarak görmektedir. Bu düşünceyi paylaşan Sühreverdî, onun dişil karakterinin nedenini, heykel efendisi olduğu toprakla ilişkilendirir. Zira toprak, mertebesinin daha aşağı olması bağlamında diğer her şeyin

12 Sühreverdî, Hikmetu'l-İşrâk, s. 142-143; Henry Corbin, Ravabit-i Hikmet-i İşrâk ve Felsefe-i İran-ı Bastan (Bonmayeha-e Ayin-i Zertoşt Der Endişe-i Sohreverdi), trc. Abdülhamid Ruhbehşan, İntişarat-1 Esatir, Tahran 1384, s. 74.

13 Sühreverdî, Hikmetu'l-İşrâk, s. 157-158.

14 Yılların ve mevsimlerin efendisi Haurvatat Yeşt. 4.00, Ahura Mazda'nın iyilerin refahı için yarattığı Haurvatat Yeşt. 4.01; Şeytanların yok edilmesi için yakarılan Haurvatat Yeşt. 4.02; Ölüm sonrası doğru insanların ödülü olan Haurvatat ve Ameretat Yeşt. 1.25; Haurvatat'ın sularla Ameretat'ın bitkilerle anılması Yesna. 3.01, 4.01, 8.01. Ahura Mazda'nın ölümsüzlüğü (Ameretat) ve bütünlüğü (Haurvatat) içermesi Yesna. 34.01, 34.11, 31.06; Yesna. 34.01, 34.11, 33.08; Anklesaria, Greater Bundahishn III.11-17, s. 30-39.

15 Dünyanın dişil koruyucusu ve dünyanın kendisi Yesna 16.10; Yeşt 13.03, 24.50; Vendidad. 2.10, 2.14, 3.35. 
etkisine açık haldedir. Bu nedenle Sühreverdî, İsfendermez'i diğer efendilere göre dişilikle tanımlamaktadır. ${ }^{16}$ Zerdüşt'ün Gatha'sında metaforik bir anlatımla Ahura Mazda'nın kızı olarak resmedilen Spenta Armaiti/ İsfendermez, diğer Ameşalar gibi birden fazla anlam halesine sahiptir. Bu bağlamda o, dindarlık ve sadakat olarak bilinirken aynı zamanda dünyanın ve dişiliğin hamiliğinin kendisine verildiği görülmektedir. Ayrıca İsfendermez, son geldiğinde canlıları yeniden diriltmeye kadir bir varlıktır. ${ }^{17}$

Sühreverdî'nin Mecûsî geleneğindeki en önemli Ameşa olan Behmen'i ${ }^{18}$, nurlar hiyerarşisinde Nuru'l-Envâr'dan sonraki ilk nur olarak takdim etmesi oldukça dikkat çekicidir. İlk nurun sudurundan bahsettiği bölümde ona Pehlevîlerin Behmen dediklerini ifade etmesi ${ }^{19}$, kendisinin de aslında bu kavramsal çerçeveye benzer bir şeyden bahsettiğini izhar etmesi anlamına gelmektedir. Buna göre Sühreverdî, Nuru'l-Envâr olarak takdim ettiği tanrıyı, zorunlu ilk varlık olarak görmekte ve onun basît olduğunu ve bu nedenle de ancak bir varlığın ondan husûl/sudûr edebileceğini düşünmektedir. Bu bağlamda husûlün/taşmanın başlangıçta en yüce nurdan tek bir taşmayla gerçekleştiğini ve onun ilk akıl veya Behmen olduğunu ifade etmektedir. Şeyhu'l-İşrâk, bu ilk taşmanın devamında nurların ziyadesiyle arttığını, çoğalmanın bu ilk nurdan gerçekleşen sudûrla vücûd bulduğunu ve her bir nur için bir berzâhın yahut maddenin var olduğunu kabul etmektedir. Fakat bu ilk nur ile Nurlar Nuru Yesna-Gatha 45.04; Sadakat ve dindarlık Yesna-Gatha. 30.07, 31.09, Ey Armaiti ve ey Aşa olan Mazda Yesna-Gatha. 33.11, İstekte bulunulan Armaiti YesnaGatha. 43.01, Dindarlığımız Yesna Gatha. 34.11; Yeniden dirilten Armaiti YesnaGatha. 30.7.

18 Geuş Urvan'a Zerdüşt'ün koruyucu olarak verilmesini sağlayan Yesna-Gatha. 21.07-10; Hikmetin sağlayıcısı Vohu Manah Yesna. 22.25, 25.06; Yeşt. 2.01, 24.41, Vendidad. 4.45; Çağriya cevap veren Vohu Manah Yesna. 36.04, 68.23; Yeşt. 1.20; Eskatolojide etkin olan Vohu Manah Yeşt. 19.96; Gernot Windfuhr, "Vohu Manah A Key to the Zoroastrian World-formula", Journal of Indo-European Studies, Vol. 12, 1984, s. 302-303; Ali Ekber Caferi, Zertoşt ve Din-i Behi, İntişarat-1 Cami, Tahran 1385, s. 137-138.

19 Sühreverdî, Hikmetu'l-Işsrâk, s. 128; Kutbuddin eş-Şirazi, Şerhu Hikmet'il-İşrâk, thk., A. Turani, M. Muhakkik, Tahran, Müessese-i Motaleat-1 İslâmî Danişgah-1 McGill Şube-i Tahran, 1379/2000, s. 311; Seyyid Hüseyin Nasr, Üç Müslüman Bilge, çev. Ali Ünal, İstanbul, İnsan Yay., 1985, s. 84; Corbin, Ravabit-i Hikmet-i İşrâk ve Felsefe-i İran-ı Bastan, s. 70. 
arasında bir kopmanın yahut ayrılmanın söz konusu olmadığını iddia etmektedir. Bu duruma güneşin ondan çıkan 1şık ve 1şınlarla birlikte düşünüldügünü misal vererek aralarında bir ayrışma öngörmez. Bununla birlikte ilk nurun, Nurlar Nuru'nu müşahedesiyle yeni bir nurun çıktığını ancak ilk nurun nur bakımından Nuru'l-Envâr'a göre eksik/fakir oluşu bir berzâhın veya bir gölgenin oluşmasına yol açmaktadır. Sühreverdî bundan sonraki sudûr silsilesinde her nur için bir berzâh olduğunu zikretmektedir. ${ }^{20}$

Sühreverdî'nin hitap ettiği kitlenin zihnindeki dini kodlara uygun bir tarz geliştirme çabasında olduğu düşünülebilir. Zira Behmen, Mecûsî geleneğinde Ahura Mazda'nın mutlak iyi düşüncesini tanımlamada kullanılır ve Zerdüşt'e vahiy getiren melekvari varlık olarak bilinir. ${ }^{21}$ Ayrıca Behmen, insan bedeninin kendisine verildiği Ameşa Spenta olarak karşımıza çıkmaktadır. Bu açıdan insana hakikat bilgisini getiren ve düşünceyi nasip eden Behmen, Zerdüşt tarafından kendisine hikmeti vermesi bağlamında ilâhîlerle yakarılan bir varlık olarak karşımıza çıkmaktadır. Öyle ki Behmen, insanın kurtuluşunu sağlayan bilgiye ve hikmete sahip Ameşa Spenta'dır. Mecûsî kozmolojisi açısından da Ahura Mazda'nın Ehrimen'e karşı varlıklarını yaratmaya başladığında ilk var ettiği varlık Behmen olması oldukça ilginç ve kayda değerdir. ${ }^{22}$ Bundan da öte ilk var edilen Behmen, Sasani dini edebiyatında tanrı Ohrmazd'ın/Ahura Mazda'nın hikmetidir ve yaratma eylemini Behmen'le başlatan Ohrmazd, sonraki yaratılış merhalesini onunla gerçekleştirmektedir. Zira söz konusu literatürde Behmen ışığın esası olduğu kabul edilmektedir. ${ }^{23}$ Zira Sühreverdî de Nuru'l-Envâr'dan ilk sudûr edenin Behmen olduğunu ifade etmekte ve bundan sonraki yaratma ve çoğalmanın ondan sonra başladığını düşünmektedir. Böylelikle hitap ettiği kitlenin anlam dünyasında kadîm geçmişten bu yana yer

20 Sühreverdî, Hikmetu'l-İşrâk, s. 107-123-130, 132-133, 177-178.

21 Vohu Manah'1n babası Yesna-Gatha. 32.08, 45.04; Vahishta Manah Yesna-Gatha. 28.09, 31.04,32.06, 33.09, 50.01; Ahura Mazda'nın yaratması Yesna-Gatha. 44.04; Vohu Mainyu Yesna-Gatha. 45.5, 48.08; Vahiy getiren Yesna-Gatha. 31.17, 43.11.

22 İyi düşünce ödül ilişkisi Yesna-Gatha. 28.07-08, 29.10; Ahura Mazda'nın ihsanı Yesna-Gatha. 43.02, 29.07-08, 31.10; Vohu Manah'a çağrı Yesna-Gatha. 28.03, 29.08; İlk yaratılan Behmen, Menoy i Hired, trc. Ahmed Tefazzoli, Tahran, İntişarat-1 Tus, 1362/1984, s. 22-23; Anklesaria, Greater Bundahišn, (III.14), s. 40-41; Dinkerd-i Heftom, trc. M. Taki Raşid Muhassal, Pejuheşgahi Ulum-i İnsani ve Motaleat-1 Ferhengi, Tahran, 1389/2010, (0.03), s. 197.

23 Anklesaria, Greater Bundahishn, (I. 53), s. 18-19; West, Bundahisn,(I.23-25), s. 9. 
etmiş kavramları yeniden ele alarak kendi düşüncesini inşada kullandığı tebarüz etmektedir.

Mecûsî geleneğindeki altı Ameşa'nın konumlarını koruyarak kendi düşüncesine aldı̆̆ı anlaşılan Sühreverdî, bir diğer Ameşa olarak zikrettiği Şehrir'in (Şehrevar), ${ }^{24}$ tılsımıyla güneşi (Hvarexshaeta, Av.; Hurakhsh, Ph.) diğer yıldızlara üstün kıldığını ifade eder. Dolayısıyla dünyayı ısıtan ve onu aydınlatan güneşin neden bir Heykel Efendiyle ilişkilendirildiği açı̆̆a çıkmaktadır. Bu noktada Sühreverdî'nin güneşin tazim edilmesinin vacib olduğunu ifade etmesi, onu kahir nurlardan birisi olarak takdim etmesiyle açılanabilir. Benzer şekilde Mecûsî geleneğinde güneş günlük olarak tazim edilmesi gereken ve adına Hurşid Niyayiş olarak bilinen dua metninin söz konusu olduğu bir varlık olarak karşımıza çıkmaktadır. ${ }^{25}$ Zira Sühreverdî'ye göre göre güneşten daha büyük hacimde yıldızların varlığına rağmen hiçbirisi gündüzü gece ve geceyi gündüz kılmaya muktedir değildir. Ayrıca ona göre paklanan insan nefislerinin Allah'a yakınlıkta güneşi vesile, iki nuru (Güneş ve Ay'1) halife ve beş gezegeni taşıyıcı olarak kabul etmesi gerekmektedir. Sühreverdî güneşi, diğer yıldızlardan nur derecesi bakımından üstün, ulu cisimlerin en büyüğü ve onun İşrâk dilinde Allah'ın veçhesi şeklinde ifade etmektedir. ${ }^{26}$

Mecûsî geleneği açısından hâkimiyet kavramının ve bütün hükümranlıkların sahibi olarak tasvir edilen Şehrevar, Gatha metinlerinde daha çok Ahura Mazda'nın egemenliği ve gücü olarak zikredilmektedir. ${ }^{27}$ Şehrevar kozmik düzen içerisindeki ilâhî varlıkların güçlerinin tanımlanmasında ve insan üzerindeki egemenlikler

24 Ahura Mazda'nın krallığı Yesna. 41.02; Metallerle anılan Kşatra Yeşt. 2.07, 10.25; Vendidad. 9.10, 16.06.

25 Zend-Avesta II, (Hurşid Niyayiş), trans. James Darmesteter, Sacred Book of East, ed. Max Müller, Clarendon, Oxford University Press, 1882, s. 349-353; Jamshed Choksy-Firoze Kotwal, "Praise and Piety: Niyayishns and Yashts in the History of Zoroastrian Praxis", Bulletin of SOAS, 68/2, 2005, s. 216-218.

26 Sühreverdî, Hikmetu'l-İ̧râk, s. 149-150, 196-197, 245-246; Şihabüddin Sühreverdî, Kitab'ul-meşari' ve'l-mutârahât, Mecmua-i Musannefat-ı Şeyhi'l-İ̧̧râk, thk. Henry Corbin, Seyyid Hüseyin Nasr, Necefkuli Habibi, Pejûheşgah-1 Ulum-u İnsani ve Motaleat-1 Ferhengi, Tahran 2001/1380, C. I, s. 494.

27 Maria C. Monna, The Gathas of Zarathustra; A Reconstruction of the Text, Amsterdam, 1978, s. 184, 191-192; Kşatra Vairya Yesna-Gatha. 51.01; Ahura Mazda'ya 
bağlamında kullanılmaktadır. Bu açıdan Ahura Mazda'nın iradesinin yeryüzünde hâkim kılınması çerçevesinde de insanın ona ibadet ve itaatte bulunması istenmektedir. İlk yaratılan varlıklardan metallerin koruyucusu olarak tanımlanan Şehrevar, insan yaşamında akrabaya yardımın yasası kabul edilirken; insan bedeninde de kemiklerin kaynağ1 olarak görülmektedir. ${ }^{28}$ Bu bağlamda Sühreverdî'nin güneşin Heykel Efendisi olarak Şehrir'e/Şehrevar'a atıfta bulunması, Mecûsî geleneğe dair derin ilgisini ortaya koymaktadır.

Sühreverdî'nin, Mecûsî terminolojiyi yerli yerinde kullandığı görülmektedir. Zira Mecûsî teolojideki Ahura Mazda-Ameşa Spentalar ilişkisinden hareketle Heykel Efendiler kavramsallaştırmasına gitmektedir. Bu varlıkların Ahura Mazda'nın en yakınındaki yardımcıları olarak Sühreverdî tarafından bilinmeleri, Sühreverdî'nin Mecûsî kutsal metin literatürü konusunda teferruatlı bir bilgiye sahip olduğu yahut bunu bilen birisiyle belki de Mecûsî bir din adamıyla teşriki mesai yaptığı fikrini de güçlendirmektedir. Ayrıca terminolojisini ve buna bağlı olarak varlık hiyerarşisini Mecûsî 1stılahlar üzerinden yeniden kurması da ilgi çekicidir.

\section{Ferre}

Sühreverdî'nin Mecûsî geleneğindeki kutsal varlıklardan sadece Ameşa Spentaları değil, diğer kimi ilâhî varlık ve unsurları da kendi düşüncesini aktarırken kullandığı görülmektedir. Bu bağlamda Mecûsî geleneğinde daha çok ilâhî baht ve talih şeklinde anlaşılabilecek ve krallar için söz konusu edilen Ferre (Khwarenah; Kharrah) kavramından bahsetmektedir. Şeyhu'l-İşrâk, onun Zerdüşt'ün bahsettiği bir ışık, bir nur olduğunu ve riyazet peşinde olanın bunu müşâhede edeceğini zikretmektedir. Bu açıdan Sühreverdî, Sâsânîlerin bilge kralı Key Hüsrev Enûşirvân'ın bu nuru müşâhede ettiğini belirtmektedir. ${ }^{29}$

ait/onun için olan hâkimiyet Yesna-Gatha. 31.06; Senin ev, bölge ve ülke üzerindeki hâkimiyetin ey Mazda Yesna-Gatha. 31.16; Ahura Mazda'nın egemenliği Yesna-Gatha. 34.01, 34.05.

28 Zarar verilemeyen idare/Kşatra Yesna-Gatha. 28.03; Aşa ve Vohu Manah ve onların hâkimiyetleri Yesna-Gatha. 29.11; Ahura Mazda'ın idaresinin yeryüzünde hâkim kılınması Yesna-Gatha. 51.01; Hâkimiyeti arzulayan Zerdüşt YesnaGatha. 33.13-14, 43.08; Anklesaria, Greater Bundahishn III.11-17, XXVIII.22, s. 30$39,252$.

29 Sühreverdî, Hikmetu'l-İşrâk, s. 156-157. 
Mitolojik kahramanların ve kralların ilâhî bir lütfa/Ferreye sahip olmakla bahtlarının açık olduğunu kabul eden Mecûsî mitolojisi bu kavramı "Khwarenah" sözcügüule adlandırmaktadır. Sanskritçede güneş anlamındaki Svar- kelimesinden veya Avestaca'da aynı anlamdaki Hvar- sözcügüunden türeyen Khwarenah, Pehlevîce'de "Farnah" Farsça'da "Ferreh"ye dönüşmüştür. Aslında tek bir kelimeyle açıklanması oldukça zor olan bu kavram, açıkçası kendisine sahip olana iyi talih ve uğur getiren bir durum olarak adeta kişinin dünya hayatındaki kaderi yahut kişinin yardımında olan ruhani bir varlık olarak tanımlanmaktadır. İlahi âlemin desteği anlamında krallar ve kahramanlarla özdeşleştirilen bu unsurun, kralların zafer kazanmasında etkili olduğuna inanılmaktadır. ${ }^{30}$

Bu bağlamda bir çeşit üstün ruh gibi algilanabilecek 'Ferreh', daha çok krallar ve kahramanlarla ilişkilendirilmiştir. Tanrının lütfu olarak ona sahip olan kralın hâkim, onu kaybedenin de esir olacağı öngörülmüştür. Bu açıdan da kadîm İran mitolojisinde Keyaniler (Kayanid/Kayvan) olarak bilinen ve son üyesi Zerdüşt'ün koruyucusu Kavi/Key Viştasp olan hanedanın üyelerinin ve Hoşeng ve Yima gibi mitsel kahramanların üyesi olduğu Pişdadiler (Pişdadiyan) hanedanının buna sahip olduğu kabul edilmektedir. Sâsânî imparatorluğunun kurucusu I. Ardeşir'in kendisi için 'Kayvan Khvarenah' ibaresini kullanmasının altında yatan gerekçe de kendisini mitolojik kahramanların soyuna bağlama çabası olarak tezahür etmektedir. ${ }^{31} \mathrm{Bu}$ bağlamda tanrı tarafından başta Zerdüşt olmak üzere Mecûsî mitolojisinin öne çıkan figürlerinin elde ettiği bu ilâhî

30 Gherardo Gnoli, "Farrah", Encyclopedia Iranica, Vol. 9, s. 312-319; Almut Hintze, Zamyad Yasht; Introduction, Avestan Text, Translation, Glossary, Reichert, Wiesbaden, 1994, s. 10-11; Helmut Humbach, Pallan Ichaporia, Zamyad Yasht; Yasht 19 of the Younger Avesta Text, Tranlation, Commentary, Harrasowitz Verlag, Wiesbaden 1998, s. 14; mitolojik kahramanların öyküleri Yeşt. 19.01-93.

31 Humbach, Ichaporia, Zamyad Yasht, s. 11-13; William Malandra, An Introduction To Ancient Iranian Religion: Readings From The Avesta and Achaemenid Inscriptions, Minneapolis, University of Minnesota Press, 1983, s. 88-89; Hintze, Zamyad Yasht, s. 9-10. Zamyad, cömert dünya'nın koruyucu meleği daha doğrusu Yazatası olarak kabul edilir. Mecûsî takviminde ayın 28. Günü Zam Hudah'a atfedilir. Sirozah. 1.28, 2.28. 
talihin şahin benzeri bir kuş formunda Feridun, Kresaspa gibi mitolojik kahramanlara ulaştığ 1 kabul edilmektedir. ${ }^{32}$ Tarihsel bağlamda Sâsânî krallarının rölyef, kitabe ve kabartmalarında başlarının üstünde resmedilen 1şık halesi Ferreh'i temsil etmektedir. 'Ferreh' ilâhî gücün kralın yardımına verildiğini sembolize etmektedir. Bunun da ötesinde Darius'un Persepolis/Taht-1 Cemşid kabartmasındaki Ahura Mazda'nın sembolü olarak kabul edilen çift kanatlı figürün elinde tuttuğu 'halka'nın da 'Ferreh' olduğu ileri sürülmektedir. ${ }^{33}$

Sühreverdî, Pertevnâme adlı farsça kaleme aldığı risalesinde hikmeti bilenlerin ve bunu elde edenlerin Nûru'l-Envâr'a teşekkür etmelerini istemektedir. Zira bu sayede kişiye 'Khurre-i Keyanid'in yani Keyanilerin ilâhî lütfunun/Ferresinin verileceğini belirtmektedir. ${ }^{34}$ Ferreh kavramı yukarıda açıklandığı üzere, ona sahip olan kişinin talih ve bahtını açık eden ve bu sayede güç veren bir unsurdur. Ancak Pertevnâme metninde "Keyanid" ifadesinin eklenmesi de söz konusudur. Bu noktada Şeyhu'l-İşrâk'ın Avesta dini edebiyatında söz konusu edilen ve Akamenid imparatorluğundan önce İran coğrafyasına hükmettiği düşünülen hanedandan bahsetmesi dikkat çekicidir. Bu mitolojik Keyanid hanedanının en önemli özelliği Zerdüşt'ün dinini kabul edişidir. Zira Avesta'nın Yeşt kitabındaki Avestaca "Kaywan Xwarenah" ifadesi Sühreverdî'de Farsça "Hurre-i Keyani" şekline dönüşmektedir. ${ }^{35}$

\section{Yezdan}

Farsça olarak yazdığı Yezdan-Şinaht adlı bir diğer risalesinin başında Allah'tan bahsederken "İzedi Teâla" diyen Sühreverdî, burada Mecûsî geleneğinde yakarılmaya ve tapınılmaya layık anlamındaki Yazata kavramının Farsçaya dönüşmüş halini kullanmaktadır. Zira

32 Zerdüşt ve Viştasp Yeşt. 19.80-89; Saoşyant Khvarenah Yeşt. 19.22; Yima/Cem Khvarenah öyküsü Yeşt. 19.26-31; Thraetone/Feridun khvarenah Yeşt. 19.38; Keresaspa Khvarenah Yeşt. 19.39-44.

33 Maria Brosius, The Persians, New York, Routledge, 2006, s. 44,67, 161-165; Parvaneh Pourshariati, Decline and Fall of The Sasanian Empire, I.B.Tauris, New York 2008, s. 48; Gikyo Ito, "Gathica XIII, Avestan Xvarenah", Orient, Vol. 11, 1975, s. 41.

34 Sohravardi, Pertevname; The book of Radiance, Farsçasıyla neşreden Hossein Ziai, California, Mazda Publishers, 1998, s. 84-85 (94. madde); Corbin, Ravabit-i Hikmeti İşrâk ve Felsefe-i İran-ı Bastan, s. 70, 88.

35 Yeşt. 19.09, 93. 
risalenin adında da "İzed" in çoğulu olan "Yezdan" kavramı yer almaktadır. Yezdan kavramı da Mecûsî teolojisinde kökleri Avesta metinlerine dayanan bir geçmişe sahiptir. Yezdan kelimesi, Zerdüşt sonrası Mecûsî teolojide tapınma fiili olan "yaz-" kelimesinden türeyen ve tapınılmaya layık unsur yahut tanrısal figür olarak tanımlanan Avestaca Yazata kelimesinin dönüşmüş çoğul halidir. Pehlevice İzed ve Yazad kelimeleriyle ifade edilen kavram çoğul olarak İzedân ve Yezdân şeklinde Pehlevîce metinlerde geçmektedir. ${ }^{36}$ Özellikle İslam fetihleri sonrasında Farsça'nın oluşmaya başladığ süreçte Yezdân kavramı anlam kaymasına uğrayarak tek tanrı şeklinde kullanılmıştır. Müslümanlar nezdinde Ehli Kitap gibi muamele gören Mecûsîlerin söz konusu çoğulluğu tek tanrı şekline dönüştürmeye mütemayil oldukları da kabul edilebilir. Zira kimi Farsça kaleme alınan Mecûsî metinlerinde Yezdân kavramının kimi zaman tek tanrı şeklinde Ahura Mazda için kullanıldığı görülmektedir. ${ }^{37}$ Aynı zamanda erken dönem İslamî edebiyatta da Yezdân Mecûsîlerin tanrısı için tekil anlamda kullanılan bir kavram olarak karşımıza çıkmaktadır. ${ }^{38}$ Sühreverdî de bu bağlamda Yezdân'1 yegâne tanrı olarak zikretmektedir.

Yezdan-Şinaht risalesinin girişinde Sühreverdî, Farsça yazmasının gerekçesini de bütün Acemlerin bundan faydalanması olarak takdim etmektedir. Bu bağlamda risalede Allah'ın kullarına iyi bir baht öngördügüunden bahsederken "Nîk Bahti" (iyi baht) ifadesine yer verdiği görülmektedir. ${ }^{39}$ Sühreverdî, burada iyi anlamına gele-

36 E. Behrami, Ferheng-i Vajehayi Avesta, yay. Haz. Feridun Cüneydi, Tahran, Neşr-i Belh, 1989/1369, c. III, s. 1157; C. Oşhidari, Danişname-i Mazdayesna, Tahran, Neşri Merkez, 1990/1371, s. 507; Aturpet-i Emetan, Dinkard VI, a, 1a, 1c, 98, s. 2-3, 3839; Tefazzoli, Menoy i Hired, 30.5, s. 48.

37 Persian Rivayats of Hormazyar and Framaz and Other, trans. E. Bamanji Dhabhar, Bombay, Cama Oriental Institute, 1932, s. 443; Mehmet Alıc1, "Yezdan", DIA, Ankara, TDV yay. 2013, XLIII, s. 512-513.

38 Ebü'l-Meali, Beyanü'l Edyan, thk: Abbas İkbal Aştiyani, Tahran 1375, s. 31-32; Ebu'l Feth Şehristanî, el-Milel ve'n-Nihal, thk: E. A. Mehna, A. H. Faur, Kahire 1994, s. 274-279; Seyyid Murtaza bin Dai Haseni Razî, Tabsirat'l-Avvam fi marifeti makalati'l Enam, thk: A. İkbal, Tahran 1364, s. 13-18; el-Kadi Ebu'1-Hasan Abdülcabbar, Şerhu'l-usuli'l-hamse, nşr. Abdülkerim Osman, Ahmed Ebû Haşim, Kahire 1988, s. 274-275, 277.

39 Şihabüddin Sühreverdî, Yezdan-Şinaht, Mecmua-i Musannefat-ı Şeyhi'l-İşrâk, thk. Henry Corbin, Seyyid Hüseyin Nasr, Necefkuli Habibi, Pejûheşgah-ı Ulum-u İnsani ve Motaleat-1 Ferhengi, Tahran 2001/1380, III, s. 404-406. 
bilecek "hub" kelimesi yerine Pehlevice kökeni olan ve dinî bir çerçevede iyi ve erdemli anlamına gelen "nik" 40 sözcüğünü kullanmayı yeğlemiş olması, onun kadîm gelenek hakkındaki geniş malumatını ve kadîm etimolojiyi kullanma arzusunu delillendirmektedir.

\section{Kutsal Mekânlar; Hurkalya, Cabalka, Cabarsa}

Sühreverdî, Hikmetu'l-İşrâk'ın sonuna doğru geldiğinde "saliklerin halleri hakkında" adlı başlıkta, insanın nuru arzulaması ve derece bakımından nurlara doğru yükselmesinden bahsetmektedir. Zira Sühreverdî, insanı oluşturan beden, ruh ve nefs üçlüsünden nefsin mutlak anlamda kahir nurlardan olan Cebrail'den husul ettiğini ve dolayısıyla maddi bedenden sıyrılarak yeniden kahir nurlara ulaşma arzusunda olan bir nefsin söz konusu olduğunu ifade etmektedir. Bu bağlamda nefsin maddedeki esaretinin, maddi bedenin varlığının devamını sağlayan yeme-içme eylemlerinden olabildiğince kaçınmakla son bulacağını ve bu riyazet hayatının nefsin üst nurları müşâhede edebilmesinin yolunu açacağını dile getirmektedir. ${ }^{41}$

İşte tam da bu noktada Sühreverdî, insanın nefsini ve ruhunu maddi âlemin unsurlarından arındırdığı ölçüde, yani daha az yiyip daha az uyuduğunda maddi âlemin ötesine geçebileceğini zikretmektedir. Şeyh'ul-İşrâk, berzahın meşguliyetlerinden sıyrılarak kutsal âleme yolculuğun başlayabileceğini ve ulûhiyete nispeti seviyesinden nefsin Hakkın işrâkâtine mazhar olacağını kabul etmektedir. Bu bağlamda da işrâkâtla nurlanan ve feleklerin yönetici kahir nurlarıyla temasa geçen nefsin sıradan insanlar için gayb olarak telakki edilen hususlara vukûfiyetinin hâsıl olacağını varsaymaktadır. Zira ona göre kahir nurların berzahları olan feleklerde her şey kayıtlıdır. ${ }^{42}$

40 Dinshah Kapadia, The Glossary of Pahlavi Vendidad, Bombay 1953, s. 5.

41 Sühreverdî, Hikmetu'l-İşâk, s. 110-116, 198-202, 216-217; Sühreverdi, “El-elvahü'limadiyye", Mecmua-i Musannefat-ı Şeyhi'l-İşrâk, thk. Henry Corbin, Seyyid Hüseyin Nasr, Necefkuli Habibi, Pejûheşgah-1 Ulum-u İnsani ve Motaleat-1 Ferhengi, Tahran 2001/1380, III, s. 138-141.

42 Sühreverdî, el-elvahü'l-imadiyye, s. 152-153; Şihabüddin Sühreverdî, Heyakilü'nnur, Mecmua-i musannefat-ı Şeyhi'l-İşrâk, thk. Henry Corbin, Seyyid Hüseyin Nasr, Necefkuli Habibi, Pejûheşgah-1 Ulum-u İnsani ve Motaleat-1 Ferhengi, Tahran 2001/1380, III s. 107-108 (7. Heykel); Sühreverdî, Hikmetu'l-İşâk, s. 223-226. 
Sühreverdî mezkûr bölümün sonunda orta dereceli saliklerin kahir nurları müşâhedesiyle onların üzerine gelen nurların, onları taşıyabileceğini ve dolayısıyla onların havada ve suyun üstünde yürüyebileceklerini kaydetmektedir. Bu açıdan söz konusu nefislerin bedenlerinden sıyrılarak maddi âlemin dışında başka bir âleme daha doğrusu misâl âlemine yükselebileceklerinden bahsetmektedir. İşte tam da bu noktada Şeyh'ul-İşrâk kadîm etimolojiye başvurarak sekizinci iklimin mekânları olarak zikrettiği Cabulk, Cabars, Hurkalya şehirlerinden söz etmekte ve bu yerleri mezkûr hâdiselerin yaşandığı bölgeler olarak takdim etmektedir. ${ }^{43}$

Sühreverdî'nin acayipliklerle dolu olarak tasvir ettiği söz konusu şehirlerin İslam öncesi Mecûsî geleneğinde söz konusu edildiği görülmektedir. Hurkalya ifadesinin ilk hali sayılabilecek 'Hukairya' Mecûsî mitolojik kahramanların hayat öykülerinin zikredildiği Yeşt metinlerinde geçmektedir. Aban Yeşt'te (Sulara Yakarış) Yima'nın/Cem'in tanrıça Anahita'ya zafer bahşetmesi için sunularını Hukairya'nın doruklarında takdim etmesi buna örnek verilebilir. Buna benzer anlatılarda Yeşt metinleri boyunca Hukairya ifadesine yer verilmektedir. ${ }^{44}$ Bununla birlikte mitolojik öykülemelerin nerede geçtiği ve ne anlaşılması gerektiği hususuna gelince, Pehlevi edebiyatta 'Hukar' ifadesinin sadece bir zirve olmadığı görülmektedir. Kutsal Hara Berezaiti/El-Burz dağının zirvesi olması bağlamında 'hug(k)ar' bütün zirvelerin üstünde bir mekânı resmetmektedir. Burası Hara dağının en üst zirvesidir ve ortasındaki nehir aracılığıyla bütün suların arındığı yerdir. Aynı zamanda Mihr Yeşt metninde de geçtiği üzere, yıldızların etrafında döndüğü, karanl1ğın, rüzgarın, soğuğun, hastalığın ve kirliliğin olmadığı bu maddi dünyanın ötesinde olan mekân, kutsal Hara Berezaiti'nin zirvesindedir. Ayrıca kötü karakterli manevi varlıkların, yani Divlerin dahi ulaşamayacağı bir yer olarak tarif edilen Hara, tanrı Mitra'nın korumasındadır ve Ameşa Spentaların ikametgâhı olarak tasvir edilmektedir. İzed Haoma'nın Mitra'ya takdimede bulunduğu yerin de Hara Berezaiti'nin en yüksek doruğu olması Hukairya'nın konumunu izhar etmektedir. Zend metinlerinde de dünyanın tam ortası olarak tarif edilen kutsal Hara Berezaiti dağının doruğu, aynı zamanda

43 Sühreverdî, Hikmetu'l-Işsrâk, s. 254; Sühreverdî, Kitab'ul-meşari' ve'l-mutârahât, Mecmua-i musannefat-ı Şeyhi'l-Işrâk, thk. Henry Corbin, Seyyid Hüseyin Nasr, Necefkuli Habibi, Pejûheşgah-1 Ulum-u İnsani ve Motaleat-1 Ferhengi, Tahran 2001/1380, I, s. 494.

44 Yeşt 5.25, 5.96; 12.23-25. 
Mecûsî geleneğinde ölüm sonrası Mitra tarafından yapılacak yarg1lamanın mekânı olan Cinvat Köprüsünün de bulunduğu yer olarak kabul edilmektedir. Parlayan güneş olarak tanıtılan Mitra'nın bu açıdan karanlığı ve kötüleri yok edici bir ışık kaynağı olduğu anlaşılmaktadır. Sasani dini edebiyatının apokaliptik metinlerinden biri olarak kabul edilen Zend-i Vehmen Yesn'de Hukairya kavramina yer verildiği görülmektedir. Tanrı Ahura Mazda'nın ilahi varlıklara (yazata/İzed) ve Ameşa Spentalara emirler vererek onun yeryüzündeki takipçilerine daha doğrusu Mecûsîlere yardım ve inayette bulunduğu mekân olarak takdim edilmektedir. ${ }^{45}$

Sühreverdî maddi dünyanın dışında ve ancak riyazetle erişilebileceğinden bahsettiği mezkûr yerlerin sekizinci iklim/bölgede olduğundan söz etmektedir. Avesta edebiyatında yeryüzünün yedi bölgeden oluştuğu ve bunların idaresinin Hoşeng ve Yima gibi mitolojik şahsiyetlerin idaresi altında olduğu ifade edilmektedir ${ }^{46}$. Gatha'dan, Avesta'ya ve Zend metinlere değin Mecûsî kutsal metin literatürüne bakıldığında, yedi ülke/bölgeden bahsedildiği anlaşılmaktadır. Gatha metninde söz konusu edilen "yedi bölge"nin Bundahişn'de yeniden ele alındığı ve bu hususun mitolojik bir dille takdim edildiği görülmektedir. Buna göre Sirius/Tiştar yıldızının yağmur yağdırmasıyla suların toprağın üzerinden yükseldiği, dünyanın yediye ayrıldığı ve bu parçalardan birinin etrafında geriye kalan altı parçanın bir araya geldiği zikredilmektedir. Aban Yeşt metninde ise Hukairya'nın doruklarından kutsal deniz Vourukasa' ya dökülen suların dünyanın bütün sularının kaynağı olduğu kabul edilmekte ve dünyanın yedi bölgesi/ülkesine suların buradan aktığına yer verilmektedir. ${ }^{47}$ Ebu Reyhan Bîrunî (ö. 453/1061?), Farslıların dünya tasavvurundan bahsederken onların dünyayı yedi

45 Yeşt 10.50-52; 5.03; 10.88, 10.116-118; 6. 01-04; 19.01; Anklesaria, Greater Bundahishn, (IX.05-07), s. 93-95; West, Bundahisn, (XII. 01-10), s. 34-36. Cinvat köprüsü için bkz. Vendidad. 19.28-31; West, Bundahisn, (XXX.33), s. 129-130; C. Cereti, ed., The Zand $i$ Wahman Yasn: A Zoroastrian Apocalypse, Serie Orientale Roma, Roma, 1995, (07.27), s. 120-121, 164; M. Raşid Taki Muhassal, ed., Zend-i Behmen Yesn, Muessese-i Motaleat ve Tahkikat-1 Ferhengi, Tahran, 1380/2001, (07.27), s. 15, 71, 96; Jal Dastur Pavry, The Zoroastrian Doctrine of a Future Life, New York, Ams Press, 1965, s. 79-98.

46 Yeşt 19. 26-31.

47 Yesna-Gatha 32.03; Yeşt. 5.03-05; Anklesaria, Greater Bundahishn, (VIII.01-07), s.91-93; Bahar, Bundahiş, s. 70-71; H. Corbin, Spiritual Body and Celestial Earth: From 
iklimden müteşekkil olarak tasnif ettiklerini ve merkezde İran'1 varsaydıklarını aktarmaktadır. ${ }^{48}$ Birunî’nin bu kaydında da görüldüğü üzere Sühreverdî'den önce de Farslıların dünya tasavvurlarının bilindiği açığa çıkarmaktadır. Bu noktada bu tasavvurun Sühreverdî tarafından muhataplarının anlam dünyasına hitap edecek şekilde kullanıldığı ortaya çıkmaktadır. Bu bağlamda kendi felsefesini inşa ederken Pers mitolojisinin kadîm ama canlı mitolojisinden hareket eden Şeyhu'l-İşrâk'in, kâmil insan tipolojisinden ve gayba muttali olma açısından Mecûsî geleneği üzerinden meşru bir zemin ihdas etmeye çalıştığ1 ifade edilebilir. Zira dünyanın yedi ikliminin ötesinde sekizinci bir iklimden söz etmesi ve belli bir riyazet halinden sonra ulaşılabilecek misal âlemini, sekizinci iklim şeklinde zikretmesi oldukça dikkate değerdir.

\section{Sonuç}

Sühreverdî’nin İşrâk düşüncesini oluştururken mezkûr kadîm etimolojileri kullanma biçimini bakıldığında; bu kavramların Şeyhu'1İşrâk tarafından bir sistemin temel yapıtaşları olarak kullanılmadığı açığa çıkmaktadır. Zira Sühreverdî, nurlar hiyerarşisine dayalı olarak inşa ettiği düşüncesini daha anlamlı ve daha bilinir kılmak için bu kadîm kavramlara yer verdiği anlaşılmaktadır. Öyle ki Sühreverdî yaşadığı çağın anlam dünyasından ve hayatının geçtiği coğrafyanın din dilinden uzak kalmamayı yeğleyerek inşa ettiği fikrin en açık ve en basit şekilde muhatap kabul ettiği kitle tarafından anlaşılmasını arzulamaktadır. Bu sebeple de kadîm İran coğrafyasına ve artalanına nüfuz eden Mecûsî geleneğinin kavramsal alt yapısını kullanmayı uygun görmektedir.

Sühreverdî'nin İşrâk düşüncesi dikkatle incelendiğinde bu kavramların Mecûsî geleneğinde öngörülen rollerinin üzerinden hareket ettiği açıkça görülmektedir. Bununla birlikte Şeyhu'l-İşrâk'ın, bu kadîm etimolojileri kendi nurlar hiyerarşisi içerisinde yeni bir bağlamda ele almayı başardığı görülmektedir. Bu durum ise İşrâk felsefesinin İran coğrafyasında benimsenmesinde etkili olmuş ve kadîm hikmetin devam ettiği fikrinin canlı kalmasını sağlamıştır.

Mazdean Iran to Shi'ite Iran, trans. Nancy Pearson, New Jersey, Princeton University Press, 1989, s. 17-24.

48 Ebu Reyhan Biruni, Kitâbü't-tefhim li-evaili stnaati't-tencim, neşr. Celaleddin Hümâî, Tahran, Silsile-i İntişarat-1 Âsâr-1 Milli, 1362/1984, s. 196-203. 


\section{Kaynakça}

Alıcı, Mehmet, “Yezdan”, DIA, Ankara, TDV yay. 2013, XLIII, s. 512-513.

Aturpet-i Emetan, Dinkard VI: The Wisdom of Sasanian Sages, trans. Shaul Shaked, Colorado, Westview Press, 1979.

Behrami, Ehsan, Ferheng-i Vajehayi Avesta, yay. Haz. Feridun Cüneydi, Tahran, Neşr-i Belh, 1989/1369 c. I-IV.

Brosius, Maria, The Persians, New York, Routledge, 2006.

Caferi, Ali Ekber, Zertoşt ve Din-i Behi, İntişarat-1 Cami, Tahran 1385.

Corbin, Henry, Ravabit-i Hikmet-i İşrâk ve Felsefe-i İran-ı Bastan (Bonmayeha-e Ayin-i Zertoşt Der Endişe-i Sohreverdi), trc. Abdülhamid Ruhbehşan, İntişarat-1 Esatir, Tahran 1384.

Spiritual Body and Celestial Earth: From Mazdean Iran to Shi'ite Iran, trans. Nancy Pearson, New Jersey, Princeton University Press, 1989.

Dinkerd-i Heftom, trc. M. Taki Raşid Muhassal, Pejuheşgahi Ulum-i İnsani ve Motaleat-1 Ferhengi, Tahran, 1389/2010.

Ebu Reyhan Biruni, Kitâbü't-tefhim li-evaili sınaati't-tencim, neşr. Celaleddin Hümâî, Tahran, Silsile-i İntişarat-1 Âsâr-1 Milli, 1362/1984.

Ebu'1 Feth Şehristanî, el-Milel ve'n-Nihal, thk: E. A. Mehna, A. H. Faur, Kahire 1994.

Ebü'l-Meali, Beyanü'l Edyan, thk: Abbas İkbal Aştiyani, Tahran 1375.

el-Kadi Ebu'l-Hasan Abdülcabbar, Şerhu'l-usuli'l-hamse, nşr. Abdülkerim Osman, Ahmed Ebû Haşim, Kahire 1988.

eş-Şirazi, Kutbuddin, Şerhu Hikmet'il-İşrâk, thk., A. Turani, M. Muhakkik, Tahran, Müessese-i Motaleat-1 İslâmî Danişgah-1 McGill Şube-i Tahran, 1379.

Gnoli, Gherardo, "Farrah", Encyclopedia Iranica, Vol. 9, s. 312-319.

Hintze, Almut, A Zoroastrian Liturgy, Wiesbaden, Harrassowitz Verlag, 2007.

Zamyad Yasht; Introduction, Avestan Text, Translation, Glossary, Reichert, Wiesbaden, 1994.

Humbach, Helmut; Ichaporia, Pallan, Zamyad Yasht; Yasht 19 of the Younger Avesta Text, Tranlation, Commentary, Harrasowitz Verlag, Wiesbaden 1998.

Ito, Gikyo, “Gathica XIII, Avestan Xvarenah”, Orient, Vol. 11, 1975, s. 35-44.

Jamaspasa, Kaikhusroo, "Fire in Zoroastrianism", K. R. Cama Oriental Institute Third International Congress Proceedings, Mumbai, Jenaz Printers, 2000.

Kapadia, Dinshah, The Glossary of Pahlavi Vendidad, Bombay 1953.

Kotwal, Firoze; Boyd, James, Persian Offering The Yasna: Zoroastrian High Liturgy, Paris, Studia Iranica, 1991. 
Malandra, William, An Introduction To Ancient Iranian Religion: Readings From The Avesta and Achaemenid Inscriptions, Minneapolis, University of Minnesota Press, 1983.

Menoy i Hired, trc. Ahmed Tefazzoli, Tahran, İntişarat-1 Tus, 1362/1984.

Monna, Maria C., The Gathas of Zarathustra; A Reconstruction of the Text, Amsterdam, 1978.

Nasr, Seyyid Hüseyin, Üç Müslüman Bilge, çev. Ali Ünal, İstanbul, İnsan Yay., 1985.

Oşhidari, Cihangir, Danişname-i Mazdayesna, Tahran, Neşr-i Merkez, 1990/1371.

Pahlavi Texts I Bundahisn, Trans. Edward W. West, Sacred Book of East, ed. Max Müller, Clarendon, Oxford University Press, 1880.

Pahlavi Texts I, Shayast la Shayast, Trans. Edward W. West, Sacred Book of East, ed. Max Müller, Clarendon, Oxford University Press, 1880.

Pavry, Jal Dastur, The Zoroastrian Doctrine of a Future Life, New York, Ams Press, 1965.

Persian Rivayats of Hormazyar and Framaz and Other, trans. E. Bamanji Dhabhar, Bombay, Cama Oriental Institute, 1932.

Pourshariati, Parvaneh, Decline and Fall of The Sasanian Empire, I.B.Tauris, New York 2008.

Purdavud, İbrahim, Gatha; Kuhenterin bahşayi Avista, Tahran, 1377. , Horde Avesta, Tahran, 1310. İbrahim, Vendidad, Tahran, 1347. İbrahim, Visperad, Tahran, 1343. İbrahim, Yesna I, Tahran, 1340. İbrahim, Yeştha I-II, Tahran, 1347.

Seyyid Murtaza bin Dai Haseni Razî, Tabsirat'l-Avvam fi marifeti makalati'l Enam, thk: A. İkbal, Tahran 1364.

Skjærvø, Prods O., Zoroastrian Texts, Harvard 2007 (Ders Notu).

Sohravardi, Pertevname; The book of Radiance, Farsçasıyla neşreden Hossein Ziai, California, Mazda Publishers, 1998.

Sühreverdi, Şihabüddin, El-elvahü'l-imadiyye, Mecmua-i Musannefat-ı Şeyhi'lİşrâk, thk. Henry Corbin, Seyyid Hüseyin Nasr, Necefkuli Habibi, Pejûheşgah-1 Ulum-u İnsani ve Motaleat-1 Ferhengi, Tahran 2001/1380, III.

, Heyakilü'n-nur, Mecmua-i musannefat-ı Şeyhi'l-işsâk, thk. Henry Corbin, Seyyid Hüseyin Nasr, Necefkuli Habibi, Pejûheşgah-1 Ulum-u İnsani ve Motaleat-1 Ferhengi, Tahran 2001/1380 I. Hikmetu'l-İşrâk, Mecmua-i Musannefat-ı Şeyhi'l-İşrâk, thk. Henry Corbin, Seyyid Hüseyin Nasr, Necefkuli Habibi, Pejûheşgah-1 Ulum-u İnsani ve Motaleat-1 Ferhengi, Tahran 2001/1380, II. 
Sühreverdî̀nin İşrâk Düşüncesini İnşâda Kadim Etimolojilerin Yeri Kitab'ul-meşari' ve'l-mutârahât, Mecmua-i Musannefat-ı Şeyhi'l-İşrâk, thk. Henry Corbin, Seyyid Hüseyin Nasr, Necefkuli Habibi, Pejûheşgah-1 Ulum-u İnsani ve Motaleat-1 Ferhengi, Tahran 2001/1380, I.

Kitab'ul-meşari' ve'l-mutârahât, Mecmua-i Musannefat-ı Şeyhi'l-Işrâk, thk. Henry Corbin, Seyyid Hüseyin Nasr, Necefkuli Habibi, Pejûheşgah-1 Ulum-u İnsani ve Motaleat-1 Ferhengi, Tahran 2001/1380, II.

Yezdan-Şinaht, Mecmua-i Musannefat-ı Şeyh-il-İşrâk, thk. Henry Corbin, Seyyid Hüseyin Nasr, Necefkuli Habibi, Pejûheşgah-1 Ulum-u İnsani ve Motaleat-1 Ferhengi, Tahran 2001/1380, III.

The Zand i Wahman Yasn: A Zoroastrian Apocalypse, trans. Carlo Cereti, Serie Orientale Roma, Roma, 1995.

Windfuhr, Gernot, "Vohu Manah A Key to the Zoroastrian World-formula", Journal of Indo-European Studies, Vol. 12, 1984, s. 269-310.

Zand-Akasih-Iranian or Greater Bundahisn, trans., Behramgore T. Anklesaria, Bombay, 1956.

Zend-i Behmen Yesn, M. R. Taki Muhassal, ed., Muessese-i Motaleat ve Tahkikat-1 Ferhengi, Tahran, 1380/2001. 


\section{MILEL VE NIHAL}

inanç, kültür ve mitoloji araştırmaları dergisi

Cilt/Volume: 11 Sayı/Number: 2 Temmuz - Aralık / July - December 2014

ISSN: 1304-5482

Bu dergi uluslararası EBSCO HOST Research Databases veri indeksi ve

TÜBITAK-ULAKBİM Sosyal ve Beşeri Bilimler Veri Tabanı tarafından taranmaktadır.

\section{Sahibi / Owner}

Milel ve Nihal Eğitim, Kültür ve Düşünce Platformu Derneği adına Şinasi Gündüz

$$
\begin{aligned}
& \text { Yazı İşleri Sorumlusu / Legal Representative } \\
& \text { Yasin Aktay }
\end{aligned}
$$

Editör / Editor

Şinasi Gündüz

Editör Yrd. / Co-Editor

Cengiz Batuk

Hakan Olgun

\section{Yayın Kurulu/ Editorial Board*}

Alpaslan Açıkgenç, Ayaz Akkoyun, Yasin Aktay, Mahmut Aydın,

Cengiz Batuk, Şinasi Gündüz, İbrahim Kayan, Hakan Olgun, Necdet Subaşı,

\section{Burhanettin Tatar}

\section{Danışma Kurulu/Advisory Board*}

Baki Adam (Prof. Dr., AÜ); Mohd. Mumtaz Ali (Prof. International Islamic U. Malezya); Adnan Aslan (Prof.Dr., Süleyman Şah Ü.); Kemal Ataman (Doç.Dr., Uludağ Ü.); Mehmet Akif Aydın (Prof. Dr., Marmara Ü.); Yılmaz Can (Prof. Dr., OMÜ); Ahmet Çakır (Doç. Dr., OMÜ); Mehmet Çelik

(Prof. Dr., Celal Bayar Ü.); Waleck S. Dalpour (Prof. University of Maine at Farmington); İsmail

Engin (Dr., Berlin); Cemalettin Erdemci (Prof.Dr. YYÜ); Tahsin Görgün (Prof.Dr., 29

Mayıs Ü.) Ahmet Güç (Prof.Dr., Uludağ Ü.); Recep Gün (Doç. Dr., OMÜ); Ö. Faruk Harman

(Prof.Dr., Mar.Ü.); Erica C.D. Hunter (Dr., Cambridge U.); Mehmet Katar (Prof. Dr., A.Ü.);

Mahmut Kaya (Prof. Dr., İ.Ü.); Sadık Kılıç (Prof.Dr., Atatürk Ü.); Şevket Kotan (Y.Doç.Dr., İ.Ü.); İlhan Kutluer (Prof.Dr., Mar. Ü.); George F. McLean (Prof. Catholic Univ., Washington DC); Ahmet Yaşar Ocak (Prof. Dr., Hacettepe Ü.); Jon Oplinger (Prof. University of Maine at Farmington); Ömer Özsoy (Prof.Dr., Frankfurt U.); Roselie Helena de Souza Pereira (Mestre em

Filofia-USP; UNICAMP Brasil); Ekrem Sarıkçıŏlu (Prof.Dr., SDÜ); Hüseyin Sarıoğlu (Prof.Dr.,

İÜ); Bobby S. Sayyid (Dr. Leeds U.); Mustafa Sinanoğlu (Prof.Dr., 29 Mayıs Ü.); Mahfuz Söylemez

(Prof.Dr. IÜ); Necdet Subaşı (Y.Doç.Dr., DİB); Bülent Şenay (Prof.Dr., UÜ); İsmail Taşpınar

(Prof.Dr. Mar.Ü.); C. Sadık Yaran (Prof.Dr., OMÜ); Ali Murat Yel (Prof.Dr., Fatih Ü.); Hüseyin Yılmaz (Doç.Dr., YYÜ); Ali İhsan Yitik (Prof. Dr., DEÜ)

* Soyadına göre alfabetik sıra / In alphabetical order

\section{Kapak ve Sayfa Tasarımı / Cover \& Page Design} İnan Avc1

Baskı / Publication

Ladin Ofset - İstanbul, Haziran 2015

2.Mat. Sit. 3 NB 15 Topkapi İstanbul / İsmail Tüz 02125012418

Yönetim Yeri / Administration Place

Milel ve Nihal Eğitim, Kültür ve Düşünce Platformu Derneği

Fevzipaşa Cad. Şehit Mehmet Sarper Alus Sok. No: 5, K.: 3, Tel: (0212) 5339731 Fatih/İstanbul www.milelvenihal.org e-posta: dergi@milelvenihal.org

Milel ve Nihal yılda iki sayı olarak altı ayda bir yayımlanan uluslararası hakemli bir dergidir. Milel ve Nihal' de yayımlanan yazıların bilimsel ve hukuki sorumluluğu yazarlarına aittir. Yayım dili Türkçe ve İngilizce'dir. Yayımlanan yazıların bütün yayın hakları Milel ve Nihal'e ait olup, yayıncının izni olmadan kısmen veya tamamen basılamaz, çoğaltılamaz ve elektronik ortama taşınamaz. Yazıların yayımlanıp yayımlanmamasından yayin kurulu sorumludur. 


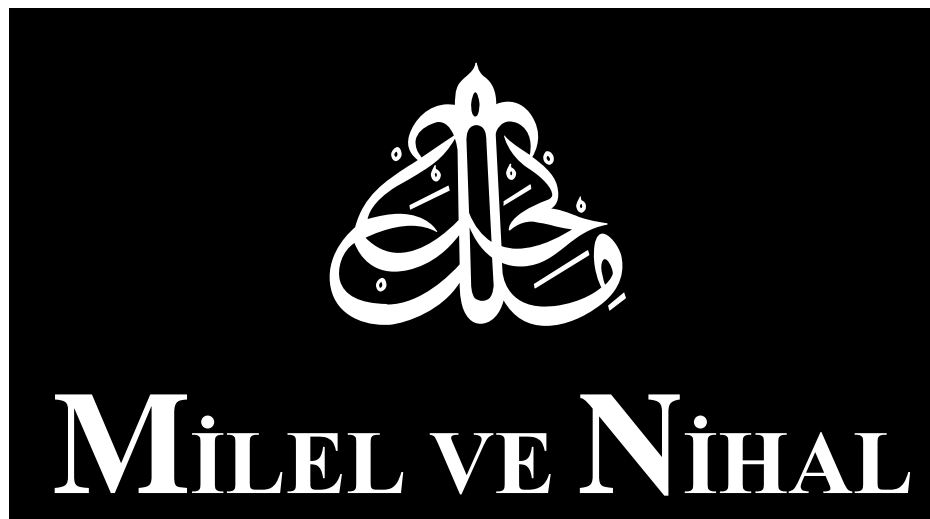

inanç, kültür ve mitoloji araştırmaları derogisi

ISSN: 1304-5482

Cilt/Volume: 11 Sayı/Number: 2

Temmuz - Aralık / J uly - December 2014 


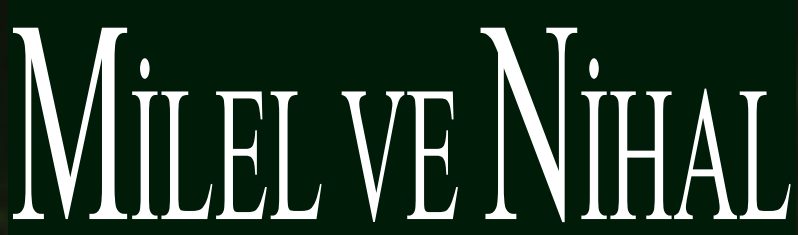

inanç, kültür ve mitoloji araştırmaları dergisi

ISSN 1304-5482

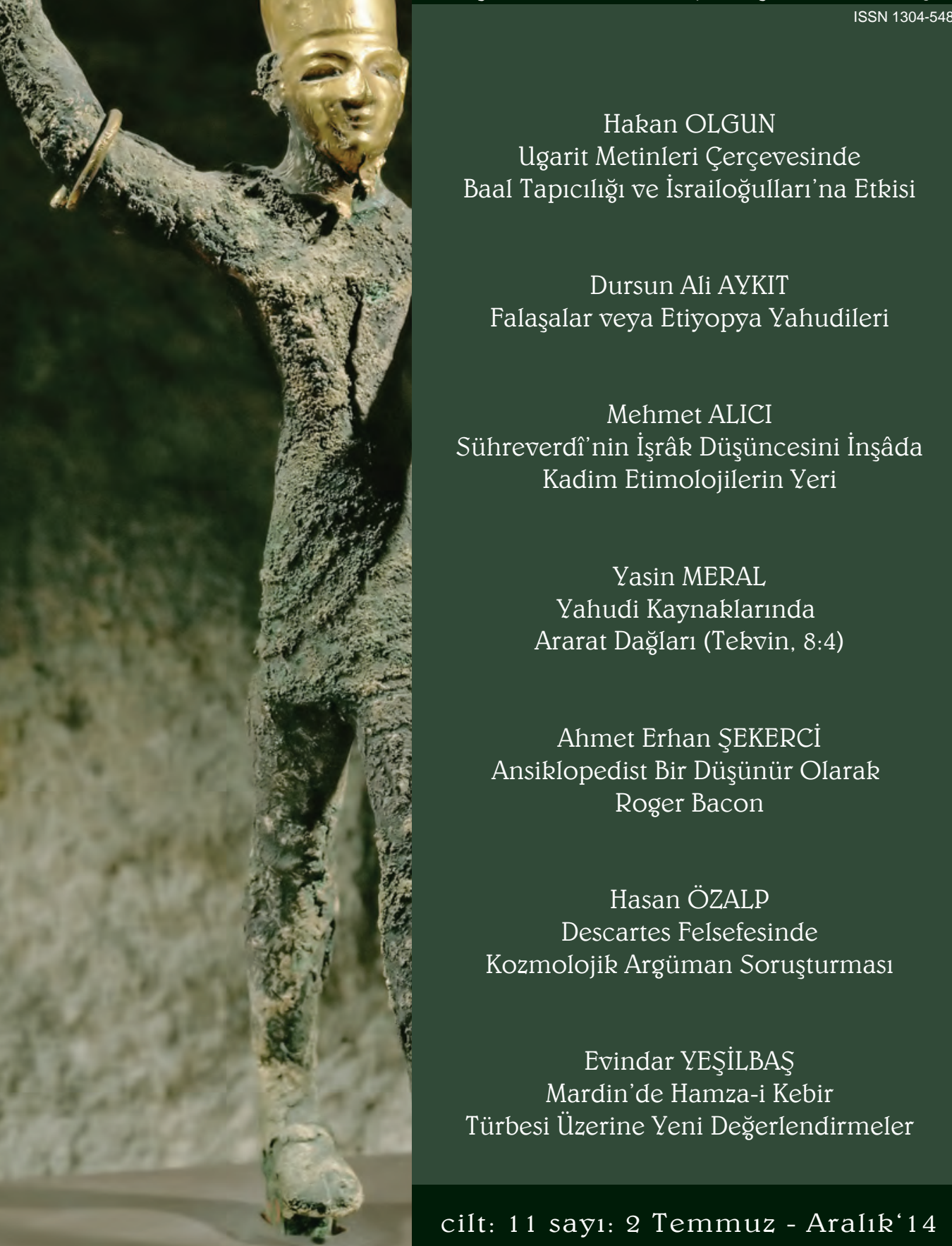

